\title{
Dampak Toxic Parents dalam Kesehatan Mental Anak
}

\section{Impact of Toxic Parents on Children's Mental Health}

\author{
Oktariani* $^{*}$ \\ Fakultas Psikologi, Universitas Potensi Utama, Indonesia \\ Disubmit: 28 Mei 2021; Diproses: 02 Juni 2021; Diaccept: 08 September 2021; Dipublish: 02 Desember 2021 \\ *Corresponding author: E-mail : oktariani1610@gmail.com
}

\begin{abstract}
Abstrak
Dalam pola toxic parenting, orang tua memperlakukan anaknya dengan tidak hormat sebagai individu, contoh tidak memuji pekerjaan anak atau, meremehkan hal-hal yang sudah anak lakukan dalam hidup kesehariannya. Atau orang tua yang suka membanding - bandingkan anak dengan anak lainnya atau membandingkan dengan saudara kandungnya sendiri sehingga mengakibatkan turunnya rasa percaya diri pada anak. Orang tua yang melakukan pola asuh ini atau toxic parents memiliki perilaku yang buruk, seperti melakukan kekerasan fisik dan juga kekerasan verbal, sehingga pada akhirnya ini menjadi racun dalam pribadi anak dan hal ini jarang di sadari oleh orang tua. Toxic parents memberikan efek negatif yang sangat besar untuk anak-anak. Anak-anak dapat menderita secara mental. Anak tipe penurut akan berusaha sekeras mungkin untuk membahagiakan orangtuanya dengan cara menekan segala hal yang mereka inginkan. Sementara untuk yang anak tipe pemberontak akan menjadi pembangkang untuk orang tuanya. Jika toxic parents ini berlangsung sepanjang kehidupan anak maka kesehatan mental anak akan mengalami gangguan. Jika kesehatan mental anak terganggu, maka akan mempengaruhi kepada perilaku anak didalam kehidupan kesehariannya.
\end{abstract}

Kata Kunci: Kesehatan Mental Anak; Toxic Parents

\begin{abstract}
In toxic parenting, parents treat their children with disrespect as individuals, for example not praising their children's work or underestimating the things that children have done in their daily lives. Or parents who like to compare comparing children with other children or comparing with their own siblings, resulting in a decrease in selfconfidence in children. Parents who practice this parenting or toxic parenting have bad behavior, such as physical and verbal violence, so that eventually this becomes toxic in the child's personality and this is rarely realized by parents. Toxic parents have a huge negative effect on children. Children can suffer mentally. Submissive children will try their best to make their parents happy by suppressing everything they want. As for the rebellious type children will become dissidents for their parents. If this toxic parent lasts throughout the child's life, the child's mental health will be disturbed. If a child's mental health is disturbed, it will affect the child's behavior in their daily life.
\end{abstract}

Keywords: Children's Mental Health; Toxic Parents

DOI: https://doi.org/10.51849/j-p3k.v2i3.107

Rekomendasi mensitasi :

Oktariani. (2021), Dampak Toxic Parents dalam Kesehatan Mental Anak. Jurnal Penelitian Pendidikan, Psikologi dan Kesehatan (J-P3K), 2 (3): 215-222. 
p-ISSN : 2721-5393, e-ISSN : 2721-5385

www.jurnalp3k.com/index.php/J-P3K/index

\section{PENDAHULUAN}

Kelahiran seorang anak di dalam keluarga, pada awalnya membawa kebahagiaan pada orang tua. Namun seiring dengan berjalannya waktu, banyak anak yang tumbuh di dalam lingkungan keluarga yang dengan kondisi orang tuanya yang kasar, memperlakukan anak dengan semena-mena, yang paling fatal adalah "meracuni "mental anak baik secara psikis dan fisik. Istilah orang tua yang "meracuni" ini di kenal dengan "toxic parent" sementara pola asuh yang di jalani orang tua di sebut dengan toxic parenting.

Menurut (Lestari, 2012) keluarga merupakan rumah tangga yang mempunyai ikatan darah ataupun pernikahan ataupun wadah yang dimana terselenggaranya fungsi- fungsi instrumental mendasar serta fungsi- fungsi ekspresif keluarga untuk para anggotanya yang terletak dalam sesuatu jaringan.

Coleman dan Cressey dalam (Saskara dan Ulio, 2020) tingkatkan, keluarga ialah sekelompok orang yang dihubungkan oleh pernikahan, generasi, maupun adopsi yang hidup bersama dalam sesuatu rumah tangga.

Apa yang terjadi dalam kehidupan kita akan memengaruhi keluarga kita, dan sebaliknya. Keluarga yang sehat tentu didambakan oleh semua orang. Ada beberapa karakteristik keluarga sehat adalah: dukungan; kasih sayang untuk semua anggota keluarga yang lain; menyediakan keamanan dan perasaan memiliki; komunikasi yang terbuka; serta memastikan setiap anggota keluarga merasa penting, dihargai, dihormati dan percaya diri, tetapi, dalam keluarga toxic, hal-hal tersebut tidak ada.

Dalam pola toxic parenting, orang tua memperlakukan anaknya dengan tidak hormat sebagai individu, contoh tidak memuji pekerjaan anak atau, meremehkan hal-hal yang sudah anak lakukan dalam hidup kesehariannya. Atau orang tua yang suka membanding - bandingkan anak dengan anak lainnya atau membandingkan dengan saudara kandungnya sendiri sehingga mengakibatkan turunnya rasa percaya diri pada anak.

Toxic parenting bukanlah konsep yang tetap dalam dunia medis namun ketika orang membahas toxic parenting atau toxic parent, hal ini dapat mengarah pada perilaku orang tua yang tidak memperlakukan anak mereka dengan baik dan menyebabkan anak merasa bersalah, ketakutan, dan merasa harus berperilaku sangat patuh pada orangtuanya.

Sikap orang tua yang bisa dikatakan toxic kala sikap memunculkan suatu pola kerutinan yang menyebabkan akibat negatif pada kehidupan anak.

Orang tua yang tercantum kategori toxic parents umumnya melaksanakan metode apapun tercantum metode yang bisa mencelakakan ataupun mengganggu anak demi penuhi kebutuhan orang tua sendiri. Contohnya melaksanakan kekerasan intim, kekerasan emosional, raga, serta pengabaian pada anak.

Berdasarkan hasil penelitian yang di lakukan oleh Carelina dan Suherman (2020) mengatakan bahwa bagi remaja toxic parent terdiri dari 3 kelompok yaitu yang pertama kategori yang memaknai 
p-ISSN : 2721-5393, e-ISSN : 2721-5385

www.jurnalp3k.com/index.php/J-P3K/index

orang tuanya toxic karena tidak adanya kepedulian terhadap anak, dalam memberikan alasan tidak adanya kepedulian terhadap anak, yang kedua subjek memaknai orang tuanya toxic karena orang tua suka membandingkan anak, dan yang terakhir ada kategori yang memaknai orang tuanya toxic karena sikap orang tua yang sampai membuat trauma anak.

Masalah kesehatan mental dapat dialami siapapun, termasuk anak dan remaja. Namun, orang tua sering kali tidak sadar bahwa anaknya memiliki masalah kesehatan mental. Kesehatan mental ini diperlukan dalam perkembangan anak. Kesehatan mental anak, jika dikembangkan dengan baik sejak masa bayi dan balita, akan membantu anak dalam menghadapi situasi apapun dan membantunya tumbuh jadi anak dan kelak orang dewasa yang sehat secara utuh.

Kesehatan mental anak merupakan bagaimana anak berpikir serta merasa dirinya sendiri dan dunia di sekelilingnya, oleh karena itu kesehatan mental berhubungan dengan gimana anak mengalami tantangan dalam hidup.

Kesehatan mental yang baik adalah kondisi ketika batin kita berada dalam keadaan tentram dan tenang, sehingga memungkinkan kita untuk menikmati kehidupan sehari-hari dan menghargai orang lain di sekitar. Seseorang yang bermental sehat dapat menggunakan kemampuan atau potensi dirinya secara maksimal dalam menghadapi tantangan hidup, serta menjalin hubungan positif dengan orang lain.
Sebaliknya, orang yang kesehatan mentalnya terganggu akan mengalami gangguan suasana hati, kemampuan berpikir, serta kendali emosi yang pada akhirnya bisa mengarah pada perilaku buruk.

Organisasi Kesehatan Dunia (WHO) mendefinisikan kesehatan mental sebagai keadaan sosial dan kesejahteraan emosional, bukan hanya tidak adanya gangguan. Dengan demikian, kesehatan mental adalah sumber daya untuk hidup, penting bagi semua anak-anak untuk berkembang dan penting bagi pembangunan manusia yang optimal dan berfungsi di sepanjang kehidupan. Lingkungan sangat berpengaruh terhadap kesehatan mental pada anak (Waddell, dalam Puspita 2019).

Data World Health Organization (WHO) tahun 2000 (dalam Puspita 2019) diperoleh angka gangguan mental yang semula $12 \%$ meningkat menjadi $13 \%$ di tahun 2001 dan diprediksi pada tahun 2020 menjadi 15\%. WHO memprediksi angka gangguan jiwa penduduk dunia meningkat hingga 15\% pada tahun 2015.

Berdasarkan laporan Riset Kesehatan Dasar (Riskesdas) 2013 di Indonesia, prevalensi penduduk yang mengalami gangguan mental emosional berumur 15 tahun ke atas secara nasional adalah 6,0\% (37.728 orang dari 703.946). Dalam jurnal Department of Health South East dijabarkan mengenai Kesehatan Jiwa pada Anak \& Young People (BMA, dalam Puspita 2019), gangguan perilaku: $6 \%$ dari 5-16 tahun memiliki gangguan perilaku yang lebih sering terjadi pada anak lakilaki. 
p-ISSN : 2721-5393, e-ISSN : 2721-5385

www.jurnalp3k.com/index.php/J-P3K/index

Gejalanya antara lain sering mengalami gangguan emosi marah, ketidaktaatan pada peraturan pemberontak atau provokatif, melakukan intimidasi, kekejaman terhadap hewan dan menyinggung perilaku. Gangguan emosional: $4 \%$ dari anak usia 5-16 tahun memiliki gangguan emosional. Mereka lebih umum pada anak perempuan dan termasuk kecemasan, depresi dan fobia. Gejalanya adalah kesedihan, mudah tersulut amarah dan kehilangan kepentingan dalam kegiatan, kelelahan , gangguan tidur, kehilangan nafsu makan, sulit berkonsentrasi, perasaan bersalah , tidak berharga dan bunuh diri dan juga mengalami gangguan hiperkinetik dimana diperkirakan $2 \%$ dari anak usia 5-16 tahun memiliki gangguan hiperkinetik .

Kesehatan mental dipengaruhi oleh peristiwa dalam kehidupan salah satunya adalah toxic parenting yang meninggalkan dampak yang besar pada kepribadian dan perilaku seseorang.

\section{METODE PENELITIAN}

Penelitian ini termasuk dalam penelitian kualititaif, dengan metode yang digunakan untuk pengkajian ini adalah studi literatur. Pengumpulan data atau sumber literature dengan menggunakan metode library research dengan berbagai sumber ilmiah dalam bentuk buku, artikel ilmiah serta literature yang sesuai dengan topik yang diambil. Kemudian data atau informasi yang diperoleh dikumpulkan, dianalisis, dan disimpulkan sehingga mendapatkan kesimpulan mengenai studi literature.

\section{HASIL DAN PEMBAHASAN}

Permasalahan di dalam keluarga memberikan sumbangan sebagian besar permasalahan gangguan mental pada anak yang kemudian dibawa anak sampai mereka tumbuh dewasa. Anak yang tumbuh dalam lingkungan keluarga bermasalah akan cenderung mengalami gangguan psikologi dan memiliki kepribadian yang rapuh. Anak yang tumbuh dalam keluarga yang bermasalahan ketika dewasa, ia akan cenderung pesimistis memandang dunia, tidak tahan stres, gampang depresi, dan memiliki kecemasan yang tinggi.

Orang yang bermasalah karena tumbuh dalam keluarga toxic memiliki kecenderungan membesarkan anaknya secara toxic juga. Akibatnya anak tersebut menjadi pribadi yang toxic juga ketika dewasa. Begitu seterusnya sampai melahirkan keturunan-keturunan bermasalah secara psikologis. Kecuali rantai setan dampak toxic parent bisa diputus dengan pembelajaran dan insigt dari orangtua dan anak.

Toxic parents (Susan Forward, 2002) mengatakan bahwa orang tua yang dikategorikan sebagai orang tua toxic, mempunyai ciri ciri seperti memperlakukan anak seperti orang yang bodoh, terlalu melindungi anaknya sehingga anaknya terkekang karena orang tuanya terlalu mengekang, terlalu membebani anaknya dengan rasa bersalah atau dengan kesalahan yang mereka perbuat lalu diungkit terus menerus oleh orang tuanya, mengatakan kata-kata yang membuat anak tidak 
p-ISSN : 2721-5393, e-ISSN : 2721-5385

www.jurnalp3k.com/index.php/J-P3K/index

percaya diri dan merasa tidak dicintai oleh orang tuanya sendiri.

Mengutip artikel yang di tulis dari TribunSumsel.com sejarah kata toxic ini berawal dari orang-orang yang bermain game serta orang-orang yang menggunakan media sosial, dalam hal mengungkapkan kekesalannya terhadap seseorang dengan menggunakan bahasa gaul Bahasa Inggris yang diplesetkan.

Toxic parents mempunyai makna adalah orangtua yang tidak menghormati dan memperlakukan anaknya dengan baik sebagai individu. Mereka melakukan berbagai kekerasan pada anak yang dalam jangka pendek akan membuat kondisi psikologis atau kesehatan mental anak akan terganggu.

Toxic parents juga tidak mau berkompromi, bertanggung jawab, maupun meminta maaf pada anaknya. Hal ini dilakukan oleh orangtua yang memiliki gangguan mental atau merupakan seorang pecandu. Keadaan ini menciptakan lingkungan yang tidak aman bagi anak, baik itu dalam bentuk kekerasan emosional, kekerasan seksual, kekerasan fisik, atau pengabaian (dalam Saskara, 2020)

Menurut (Indrawati, Endang et al., 2014) keluarga toxic memberikan efek jangka panjang bagi anak, terutama pada sisi psikologis yang dapat mengakibatkan trauma. Terlebih lagi, trauma ini justru berpotensi kepada penerapan pola hidup toxic tersebut kepada keluarga yang akan anak ini bangun di masa mendatang.

Menurut Forward \& Buck (2002) di dalam keluarga toxic ada kepercayaan dan peraturan tidak tertulis yang hampir semuanya lebih terpusat kepada perasaan dari orang tua toxic.

Berikut adalah contoh kepercayaan yang tidak tertulis: (1) Anak harus menghormati dan menghargai orang tua dalam kondisi apapun, (2) Ada dua cara dalam melakukan sesuatu - cara kami atau cara yang salah, (3) Anak harus dapat dilihat tapi tidak boleh didengar, (4) Anak salah apabila marah kepada orang tuanya. Contoh peraturan tidak tertulis dari keluarga toxic adalah: (1) Jangan sukses melebihi ayah, (2) Jangan lebih bahagia dari ibu, (3) Jangan mengikuti jalan anak, (4) Jangan pernah berhenti membutuhkan sang orang tua.

Apabila anak-anak tidak mengikuti aturan dan kepercayaan toxic ini, orang tua toxic biasanya bereaksi dengan memberikan hukuman, atau menahan cinta mereka. Akhirnya, anak akan tetap mengikuti peraturan keluarga toxic hanya karena mereka tidak mau dihukum. Atau, lebih lagi, anak-anak tidak mau menjadi penghianat keluarga karena tidak patuh, tidak peduli seburuk apa pun posisi anak. Hal seperti inilah kemungkinan akan sangat mempengaruhi faktor kesehatan mental anak (Saskara, 2020).

Menurut Sri Juwita Kusumawardhani, M.Psi., Psikolog (dalam Latifa, 2015) mengatakan bahwa toxic parent adalah istilah populer yang digunakan untuk menyebut disfunctional family. Sri Juwita Kusumawardhani, M.Psi., Psikolog Psikolog (dalam Latifa, 2015) mendefinisikannya sebagai keluarga yang tidak berfungsi sebagaimana mestinya atau tidak sehat. Toxic parent adalah orang tua yang tidak 
p-ISSN : 2721-5393, e-ISSN : 2721-5385

www.jurnalp3k.com/index.php/J-P3K/index

mampu memberikan rasa aman kepada anaknya.

Menurut Sri Juwita Kusumawardhani, M.Psi., Psikolog (dalam Latifa, 2015) , orang tua yang toksik tidak bisa memenuhi kebutuhan anak-anaknya. Orang tua pada umumnya berpikir bahwa kebutuhan anak hanyalah makan, minum, rumah, atau sekolah. Namun orang tua lupa bahwa anak-anak tidak hanya memiliki kebutuhan fisik, melainkan juga kebutuhan emosional. Misalnya kedekatan dan kehangatan dengan orang tua, berbicara dari hati ke hati antara orang tua dengan anak.

Menurut Sri

Juwita Kusumawardhani, M.Psi., Psikolog (dalam Latifa, 2015), ciri - ciri toxic parents adalah :

1. Menelantarkan Kebutuhan Emosional Anak

2. Terlalu Pedas Mengkritik

3. Anak adalah Pencapaian

4. Menyalahkan Anak atas Emosinya

Toxic parents memberikan efek negatif yang sangat besar untuk anakanak. Anak-anak dapat menderita secara mental. Anak tipe penurut akan berusaha sekeras mungkin untuk membahagiakan orangtuanya dengan cara menekan segala hal yang mereka inginkan. Sementara untuk yang anak tipe pemberontak akan menjadi pembangkang untuk orang tuanya.

Jika toxic parents ini berlangsung sepanjang kehidupan anak maka kesehatan mental anak akan mengalami gangguan. Jika kesehatan mental anak terganggu, maka akan mempengaruhi kepada perilaku anak didalam kehidupan kesehariannya.

Kesehatan mental memiliki hubungan yang bersifat kontinum. Kesehatan mental dan mental illness ditentukan oleh berbagai faktor biologis, psikologis serta sosial, seperti kesehatan dan penyakit pada umumnya. Jika dilihat dari kontinumnya, kesehatan mental yang tidak diperhatikan dapat berkembang menjadi mental illness. Keadaan ini relatif menetap namun dapat berubah seiring waktu ataupun situasi yang dialami individu.

Individu yang sehat mental atau memiliki positif mental health mampu menghadapi berbagai situasi dalam kehidupan dan dapat menyesuaikan diri dengan baik. Individu menunjukkan kesejahteraan dan merasakan kebahagiaan. Salah satu ciri individu yang sehat mental adalah memiliki resiliensi.

Resiliensi didefinisikan sebagai proses dinamis dimana individu menunjukkan fungsi adaptif dalam menghadapi kesulitan yang signifikan (Luthar et al., 2000 dalam Schoon, 2006). Resiliensi merupakan kapasitas untuk mengatasi kesulitan dan menghadapi berbagai peristiwa dalam hidup. Resiliensi erat kaitannya dengan kemampuan dalam menyesuaikan diri. Ketika individu mampu menyesuaikan diri, mampu mengatasi kesulitan dan bangkit dari kesulitannya,

Menurut data WHO 450 juta orang di seluruh dunia memiliki gangguan kesehatan mental, dengan prevalensi $20 \%$ kejadian terjadi pada anak-anak (O’Reilly, 2015). Kesehatan mental anak 
dan remaja dapat mempengaruhi masa depan dirinya sendiri sebagai individu, dan berdampak pada keluarga hingga masyarakat, untuk mengetahui kesehatan mental anak, penting untuk melihat faktor dalam diri anak, keluarga dan lingkungan.

Faktor dalam diri anak seperti faktor genetik, temperamen, dan kesehatan fisik perlu diamati. Faktor dari keluarga meliputi pola asuh orang tua serta kelekatan anak terhadap orang tua. Teori kelekatan (attachment) dari John Bowlby (1969) memperlihatkan bahwa anak-anak perlu membangun ikatan yang aman dengan pengasuh utama mereka di masa kecil (Cooper, 2005).

Ikatan yang aman ini penting untuk membangun kepercayaan dan rasa aman. Dengan adanya kedua hal tersebut, mereka dapat belajar dan melakukan eksplorasi terhadap dunia di sekitar mereka dengan percaya diri dan tanpa ketakutan yang berlebihan. Pola asuh orang tua sangat berpengaruh terhadap rasa aman anak.

Adanya peraturan yang berlebihan, tuntutan yang tidak realistis, kebebasan tanpa batasan aturan, dan pola komunikasi yang tidak didasari oleh alasan-alasan mengapa pesan tersebut harus dilaksanakan memiliki pengaruh yang signifikan terhadap kesehatan mental anak.

Kesehatan mental anak yang dibesarkan dengan orang tua yang toxic akan mengalami gangguan ketika anak beranjak tumbuh dewasa, perilaku yang akan muncul pada anak yang memiliki toxic parent, adalah : (1) Memiliki kecemasan tinggi, perasaan ketakutan dan tidak aman yang sangat besar terhadap lingkungan. (2) Merasa kesepian dan tidak ada yang memahami dan mengerti dirinya, (3) Sering bersikap tidak konsisten, kesulitan membangun prinsip dan nilai hidup. (4) Dorongan agresif keluar, ingin menentang aturan sosial, melawan figur dominan. (5) Mengembangkan pertahanan diri yang sangat kuat sehingga menutupi diri mereka yang sesungguhnya/tidak mengenal diri sendiri. (6) Kesulitan mengekspresikan emosi, respon emosi terkadang tidak sesuai dengan stimulus yang diberikan. (7) Tidak memiliki tujuan pribadi yang jelas. Tujuan mereka seringkali untuk membahagiakan orangtua mereka. (8) Merasa tidak bisa membangun kedekatan emosioal dengan orang lain. (9) Kesulitan beradaptasi dengan lingkungan sosial. (10) Kesulitan berempati dan memberikan kasih sayang yang tepat kepada orang lain. (11) Terlalu patuh atau sebaliknya, menjadi sangat memberontak kepada orang lain. (12) Memiliki ketergantungan yang kuat pada orang selain dirinya. (13) Selalu menyalahkan orangtua ketika bertemu dengan masalah-masalah dalam hidup. (14) Dalam level yang lebih berat akan munculnya gangguan kecemasan, gangguan fisik, dan depresi.

\section{SIMPULAN}

Setiap orang tua selalu berusaha untuk menjadi orang tua yang terbaik bagi anak-anaknya. Namun pada kenyataannya banyak orang tua menjadi toxic parents bagi anak - anaknya. Toxic parents di lakukan orang tua dengan 
p-ISSN : 2721-5393, e-ISSN : 2721-5385

www.jurnalp3k.com/index.php/J-P3K/index

alasan untuk kebaikan anak mereka namun orang tua tidak menyadari efek negatif yang akan ditimbulkan pada anak ketika anak tumbuh dewasa.

Seorang anak yang mempunyai Toxic

parents akan mengakibatkan seorang

\section{DAFTAR PUSTAKA}

Carelina, S., \& Suherman, M. (2021). Makna Toxic Parents di Kalangan Remaja Kabaret SMAN 10 Bandung.

Forward, S., \& Buck, C. (1991). Toxic Parents, overcoming their full legacy and reclaiming your life.

Indrawati, E. S., Hyoscyamina, D. E., Qonitatin, N., \& Abidin, Z. (2014). Profil keluarga disfungsional pada penyandang masalah sosial di Kota Semarang. Jurnal Psikologi Undip, 13(2), 120-132.

Lela Latifa (2015) 5 Ciri Toxic Parent https://www.parenting.co.id/keluarga/5ciri-toxic-parent / 20 Februari 2021

Lestari, S. (2012). Psikologi Keluarga; penanaman nilai dan penanganan konflik dalam keluarga

Lester, J. N., \& O'Reilly, M. (Eds.). (2015). The Palgrave handbook of child mental health. Springer.

Puspita, S. M. (2019). Kemampuan Mengelola Emosi Sebagai Dasar Kesehatan Mental Anak Usia Dini. SELING: Jurnal Program Studi PGRA, 5(1), 85-92.

Kepmenkes, R. I. (2013). Riset Kesehatan Dasar Badan Penelitian dan Pengembangan Kesehatan.

Saskara, I. P. A., \& Ulio, S. M. (2020). Peran komunikasi keluarga dalam mengatasi "toxic parents" bagi kesehatan mental anak. PRATAMA WIDYA: JURNAL PENDIDIKAN ANAK USIA DINI, 5(2), 125134.

Tribun Sumsel. 2019. "Arti Kata Toxic ? Kata yang sering digunakan dalam game online dan media sosial". Senin 9 September 2019. /3 Maret 2021

Website seminar parenting : Menghadapi Orang Tua https://deepapsikologi.com/websiteseminar-parenting-menghadapi-orangtuatoxic /3 Maret 2021 anak mempunyai harga diri yang rendah karena mereka ketika kecil selalu tidak di hargai, selalu disalahkan ketika mereka melakukan kesalahan dan ini akan mempengaruhi kepribadiannya ketika dewasa nanti.

Oktariani, O., \& Rainata, W. (2021, July). Peningkatan Pemahaman Perkembangan Bahasa Anak di Kid Care Children Therapy Centre. In Journal of Social Responsibility Projects by Higher Education Forum (Vol. 2, No. 1, pp. 36-38).

Oktariani, Z. (2019). Meningkatkan Kepercayaan Diri dan Menumbuhkan Sikap Sosial Pada Anak Di Panti Asuhan Al Kahfi Cab. Medan. SINDIMAS, 1(1), 320-323.

Nurvica Sari, O. (2019). Mengenal dan Mengidentifikasi Kecerdasan Majemuk Pada Anak. SINDIMAS, 1(1), 334-337. 